Rapp. Grønlands geol. Unders. 81, 57-67 (1977)

\title{
DYKE INTRUSIONS ALONG THE SOUTH COAST OF DISKO
}

\author{
Asger Ken Pedersen
}

\section{Introduction}

The south and south-west coast of Disko from Mellemfjord to Godhavn provides a more than $70 \mathrm{~km}$ long section through the early Tertiary plateau basalts of West Greenland. It forms the south-westernmost on-shore part of a large lava plateau known to extend far off-shore (Park et al., 1971; Denham, 1974; Clarke, 1975).

This paper reports briefly the results of a week's reconnaissance, where dyke intrusions along the entire coast and in the fjords, from Godhavn to Eqaluit (Nordre Laksebugt) were investigated. Similar observations from Eqaluit to Mellemfjord are also reported. The purpose of the reconnaissance was to obtain information on the magmatic evolution of rocks younger than the exposed lavas, to search for native iron bearing intrusions of possible economic importance and to investigate the dyke intensity and intrusion pattern.

The area has been investigated by Giesecke (1823), Rink (1853), Steenstrup (1882, 1883, 1900), Krueger (1928a, b), Drever \& Livingstone (1948), Munck \& Noe-Nygaard (1957), Deutch \& Kristjansson (1974) and Fundal (1975) but apart from the surroundings of Godhavn, the information is very scarce. To the west of Godhavn, the native iron bearing dyke of Uivfaq has been the subject of numerous studies [see bibliographies in Bøggild (1953), Vaasjoki (1965), Pauly (1969) and Fundal (1975)]. This occurrence will not be mentioned further.

\section{General geology}

Fig. 23 shows the general geology of the area. From Godhavn and northwards a Precambrian gneiss ridge is exposed as windows where erosion has removed the cover of basalts.

Just east of the gneiss ridge, a Tertiary basin with sediments from the Upper Atanikerdluk Formation extends north-south. Tertiary plateau basalts from the Rinks Dal member of the Maligât Formation (Table 6) cover the gneisses and the sediments. At the early stage of volcanic activity within the area, the Tertiary sedimentary basin was water filled, at most a few hundred metres deep, and this basin was filled up by large tholeiitic flood basalts, which when encountering the water developed into subaqueous lava tongues or pillow breccias.

\section{Dyke intrusions}

A number of dyke types has been encountered. The dyke types met are: (1) dolerites older than the lavas, found only cutting gneisses; (2) feldsparphyric tholeiitic dykes intrud- 


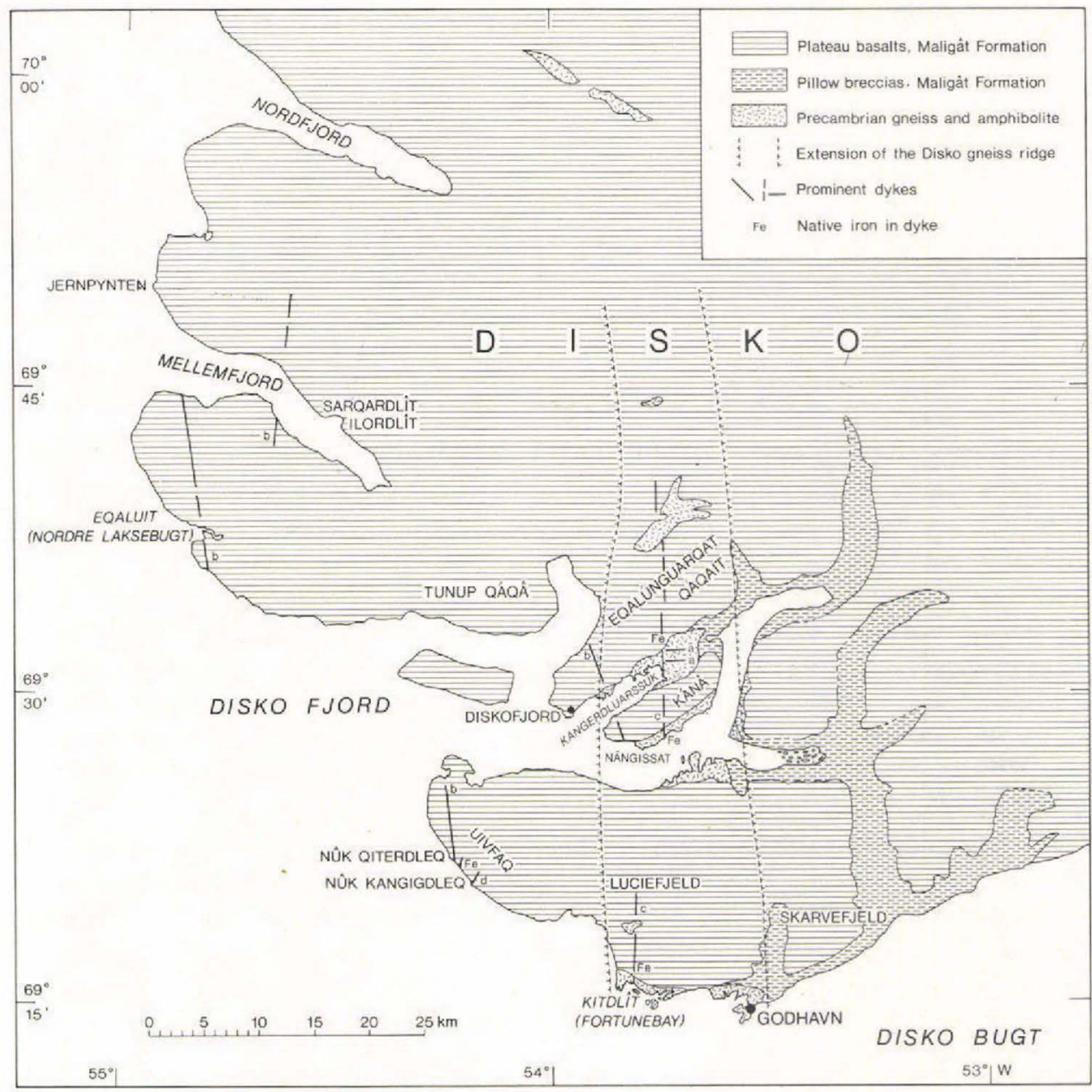

Fig. 23. Schematic geological map over southern Disko, slightly modified from the geological map sheet 1:500000 Søndre Strømfjord - Nûgssuaq. A few prominent dyke intrusions are shown. a: Pre-Tertiary tholeiitic basalts, b: Ferrotholeiitic titanium-rich basalts, c: The Nängissat-Kitdlît dyke with native iron, $\mathrm{d}$ : the intrusive, cross-bedded, breccia dyke.

ing and sometimes possibly feeding the feldsparphyric plateau basalts; (3) ferrotholeiitic basaltic dykes, definitely younger than all exposed lavas of Disko, and (4) native iron and sulhpide-bearing intrusives. Finally an intrusive breccia dyke is briefly described.

\section{Dolerites older than the Rinks Dal member lavas}

Two basaltic dykes, each 10 to $15 \mathrm{~m}$ thick striking about $\mathrm{E}-\mathrm{W}$ intrude the Disko gneiss ridge in the area a few kilometres NE of Kangerdluarssuk, east of the settlement Diskofjord. The dykes do not cut through the overlying Rinks Dal member basalts and are 
definitely older. The dykes are well crystallized, medium grained, one appears slightly feldsparphyric while the other shows no distinct phenocrysts. They are tholeiitic basalts consisting predominantly of plagioclase and augite; a few subordinate pseudomorphosed grains may be altered olivine. Late stage, scarce, green clinoamphibole and biotite occur and distinguish these rocks from the tholeiitic dykes intruding the lavas. A chemical analysis is presented in Table 9, no. 1. It is a tholeiitic basalt slightly olivine normative. Compared to most feldsparphyric tholeiitic basalts in the province, it is low in $\mathrm{TiO}_{2}$ and $\mathrm{P}_{2} \mathrm{O}_{\text {s }}$ but otherwise similar to many early Rinks Dal member basalts.

Since green amphibole or biotite is never found in the feldsparphyric tholeiitic dykes cutting lavas, nor in the lavas, it is concluded that the present dyke exposures in the gneiss windows cooled below the palaeosurface in pre-Tertiary times, and that substantial erosion took place between the emplacement of the dykes and the volcanic burial of the gneiss hills.

\section{Feldsparphyric tholeiitic basalt dykes}

Several feldsparphyric tholeiitic dykes occur throughout the area, where they intrude or cut through feldsparphyric basalts from the Rinks Dal member. The dykes trend from NNW to NNE, most dominant being $\mathrm{N}$. The dykes vary in thickness from less than $1 \mathrm{~m}$ to $15 \mathrm{~m}$ and are approximately vertical columnar-jointed, often they intrude in an en echelon pattern.

No dykes have been proved to be feeders to lavas but some of them develop into a number of small irregular bodies which thin out and disappear upwards when observed in steep walls. Such dykes may be feeders, but only detailed field observations can confirm this.

Plagioclase, less commonly augite and scarce olivine are the phenocrysts, which rarely exceed $5 \mathrm{~mm}$ in size. Under the microscope the dyke rocks strongly resemble feldsparphyric basalts from the Rinks Dal and Niaqussat members, and presumably they represent the intrusive equivalents and sometimes feeders to these lavas.

Steenstrup (1900) described irregular highly columnar jointed basalt intrusions in the breccias in the Godhavn area. Some of these stand out as isolated, small, near-shore islands. Most, if not all, of these so-called intrusives are part of subaqueous lava tongues, formed when voluminous fast-moving lava floods poured into shallow water.

\section{Ferrotholeiitic dykes}

A generation of black dykes with red-brown, rusty weathering colour cuts through all the exposed lavas and represents the youngest recorded magmatic episode on Disko. They have been found from the Uivfaq area in the south and along the entire west coast of Disko. The dykes vary in thickness from less than $1 \mathrm{~m}$ to $15 \mathrm{~m}$, they are mostly vertical but may form inclined sheets. Dominant trends are from $\mathrm{N}$ to $\mathrm{NNW}$, but a few thin dykes strike approximately E-W. Most prominent is a $15 \mathrm{~m}$ thick sheet striking NNW and dipping $48^{\circ} \mathrm{W}$, which is exposed for $15 \mathrm{~km}$ from Eqaluit to Mellemfjord (Plate 1 and fig. 24). Another prominent dyke strikes about N-S from Nûk qiterdleq and northwards in the Uivfaq area. Some dykes have intruded water-rich, earlier established, fault zones and have developed into glass-rich breccias and pillows veined by numerous thin dyke bodies.

Some basalts are nearly aphyric, while others may contain tabular plagioclase up to $1 \mathrm{~cm}$ 


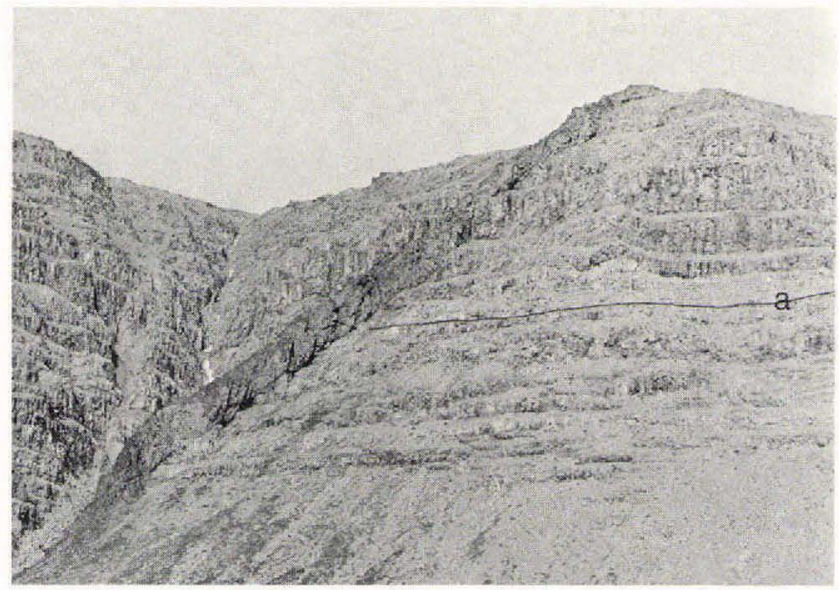

Fig. 24. Thick inclined ferrotholeiitic sheet dipping $48^{\circ} \mathrm{W}$. The sheet belongs to the generation of late titanium-rich basalts and intrudes basalts from the Nordfjord and Niaqussat members. Cleft north of Eqaluit. a: Iron-bearing lava, here constituting two flow tongues, at the base of the

Niaqussat member.

in size and augite up to $2 \mathrm{~mm}$. All contain microphenocrysts of olivine, plagioclase and augite; chromite is lacking. Significantly Fe-Ti oxides do not belong to the microphenocryst generation. In some dykes cognate gabbroid inclusions up to $2-3 \mathrm{~cm}$ in size occur. Two chemical analyses are presented in Table 9, no. 2 and 3. The rocks are slightly olivine normative, and their normative feldspars are andesine. They are remarkably high in iron, and their titanium content, which reaches as high as 5 per cent in separated glass, clearly exceeds all hitherto known volcanic rocks from the province. It shows, that the magma type could contain substantial amounts of iron and titanium without precipitating Fe-Ti oxides as near liquidus phases. Nomenclature for such rare, extreme tholeiitic differentiates is not well established. Following Irvine \& Baragar (1971) they are tholeiitic basalts although andesine normative. The rocks will be called ferrotholeiitic basalts. A number of the black dykes are less evolved than the analysed ones to judge from microscopy, although presumably still very iron and titanium rich.

The ferrotholeiitic basalts compare best, within the Tertiary volcanic province, with a generation of late dykes from Hareøen and Nûgssuaq described by Hald (1976) as transitional basalts, being however definitely less sodic but clearly more iron and titanium rich and with a distinctly higher content of normative hypersthene.

It is very likely that several of the late dykes on Disko were feeders to highly evolved iron-titanium-rich basalts which were later completely removed by erosion. Late dykes of lamprophyric, alkali basaltic or non-basaltic compositions were most carefully searched for but not found.

\section{Sediment contaminated dykes}

Sulphide and iron mineralizations have been reported from sediment contaminated intrusive bodies in north-west Disko (Pedersen, 1975; Ulff-Møller, this report). Because they combine considerable academic and economic geological interest, a careful search for such dykes was carried out together with F. Ulff-Møller. A sample of iron-bearing intermediate rock from a dyke at 'Tunnu' (Tunup qáqâ) taken by $\mathrm{H}$. Rink last century led to a special search in this area, but the intrusive body was not localized. On the other hand, a pyrrhotite 
Table 9. Chemical analyses of dykes from Disko

\begin{tabular}{|c|c|c|c|c|c|c|}
\hline & 1 & 2 & 3 & 4 & 5 & 6 \\
\hline $\mathrm{SiO}_{2}$ & 49.19 & 46.99 & 46.24 & 51.20 & 51.74 & 49.76 \\
\hline $\mathrm{TiO}_{2}$ & 1.45 & 4.55 & 4.59 & 1.38 & 1.38 & 1.42 \\
\hline $\mathrm{Al}_{2} \mathrm{O}_{3}$ & 14.58 & 11.82 & 11.70 & 13.78 & 13.87 & 14.03 \\
\hline $\mathrm{Fe}_{2} \mathrm{O}_{3}$ & 1.51 & 4.25 & 2.66 & 0.00 & 0.00 & 0.00 \\
\hline Feo & 11.11 & 12.28 & 13.93 & $9.48^{*}$ & $9.30 *$ & 10.14 \\
\hline$M n O$ & 0.23 & 0.28 & 0.27 & 0.17 & 0.18 & 0.19 \\
\hline $\mathrm{MgO}_{\mathrm{g}} \mathrm{O}$ & 6.48 & 4.68 & 4.92 & 10.10 & 10.14 & 10.80 \\
\hline $\mathrm{CaO}$ & 10.95 & 9.54 & 9.90 & 9.09 & 9.18 & 10.18 \\
\hline $\mathrm{Na}_{2} \mathrm{O}$ & 2.18 & 2.82 & 2.41 & 1.95 & 1.77 & 1.83 \\
\hline $\mathrm{K}_{2}{ }^{0}$ & 0.42 & 1.00 & 0.86 & 0.63 & 0.54 & 0.43 \\
\hline $\mathrm{P}_{2}{ }^{0}{ }_{5}$ & 0.14 & 0.64 & 0.55 & 0.15 & 0.16 & 0.13 \\
\hline $\mathrm{H}_{2} \mathrm{O}^{+}$ & 1.04 & 0.86 & 1.20 & 0.96 & 0.96 & 0.16 \\
\hline \multirow[t]{2}{*}{$1.0 .1 .+$} & 0.61 & 0.40 & 0.24 & 0.48 & 0.43 & 0.16 \\
\hline & 99.89 & 100.11 & 99.47 & 99.37 & 99.65 & 99.23 \\
\hline Total Fe as Feo & 12.47 & 16.05 & 16.32 & 9.48 & 9.30 & 10.14 \\
\hline Cr in $\mathrm{ppm}$ & - & 55 & 67 & 794 & 821 & 1018 \\
\hline C.I.P.W. norm wt. $\not \%$ & $\neq$ & $\neq$ & $\neq$ & & & \\
\hline Q & - & - & - & 0.01 & 1.65 & \\
\hline or & 2.48 & 5.91 & 5.08 & 3.72 & 3.19 & 2.54 \\
\hline$a b$ & 18.45 & 23.86 & 20.39 & 16.50 & 14.98 & 15.48 \\
\hline an & 28.76 & 16.64 & 18.57 & 26.99 & 28.31 & 28.80 \\
\hline di & 20.43 & 22.22 & 22.57 & 13.95 & 13.18 & 16.99 \\
\hline hy & 22.20 & 13.95 & 17.59 & 33.80 & 33.97 & 23.70 \\
\hline 01 & 0.48 & 2.80 & 0.66 & - & - & 8.41 \\
\hline mt & 2.39 & 3.07 & 3.13 & - & - & - \\
\hline i 1 & 2.75 & 8.64 & 8.72 & 2.62 & 2.62 & 2.70 \\
\hline ap & 0.33 & 1.52 & 1.30 & 0.36 & 0.38 & 0.31 \\
\hline Katanormative plagioclase & 59.5 & 39.7 & 46.2 & 60.7 & 64.0 & 63.7 \\
\hline $\mathrm{Mg} /\left(\mathrm{Mg}+\mathrm{Fe}_{\text {total }}\right)$ cation $\mathscr{F}$ & 0.48 & 0.34 & 0.35 & 0.66 & 0.66 & 0.65 \\
\hline
\end{tabular}

* Not analysed for Fe metal. Total Fe given as Feo.

tLoss on ignition minus $\mathrm{H}_{2} \mathrm{O}^{+}$.

* $\mathrm{Fe}_{2} \mathrm{O}_{3} / \mathrm{FeO}$ ratio of 0.15 assumed in norm calculation.

1 Pre-Tertiary tholeiitic basalt $40 \mathrm{~cm}$ from the margin of a 12 m thick dolerite dyke cutting the Precambrian gneiss. Little valley $1 \mathrm{~km} \mathrm{NE}$ of the head of Kangerdluarssuk, Disko Fjord. GGU 176654.

2 Feldoparphyric ferrotholeitic basalt. 3 m from the contact of $15 \mathrm{~m}$ thick inclined sheet. Cleft just north of river mouth in Eqaluit. GGU 176601.

3 Ferrotholeitic basalt. Glassy margin of dyke pillow developed in 4 m thick dyke. Large cleft just north of the abandoned settlement Sarqardlft ilordit, Mellemfjord, at 890 m. GGU 176554 .

4 Olivine microporphyritic iron-bearing basalt. $40 \mathrm{~cm}$ from the margin of $6 \mathrm{~m}$ thick dyke (northern part of the Nãngissat-Kitdlit dyke). North of bay east of Nãngissat on Kánâ, Disko Fjord. GGU 176646.

5 Olivine microporphyritic iron-bearing basalt $30 \mathrm{~cm}$ from the margin of 6 to $8 \mathrm{~m}$ thick dyke (southern part of the Kitdilt-Nãngissat dyke). Cleft near point 665 in the southern part of Luciefjeld at 650 m. South Disko. GGU 176661 .

6 Olivine microporphyritic contaminated basalt. Glassy apophyses in thin pahoehoe lava. Cleft in the north wall of Rinks Dal. SH of point 710 at $442 \mathrm{~m}$. North-west Disko. GGU 156647 . 


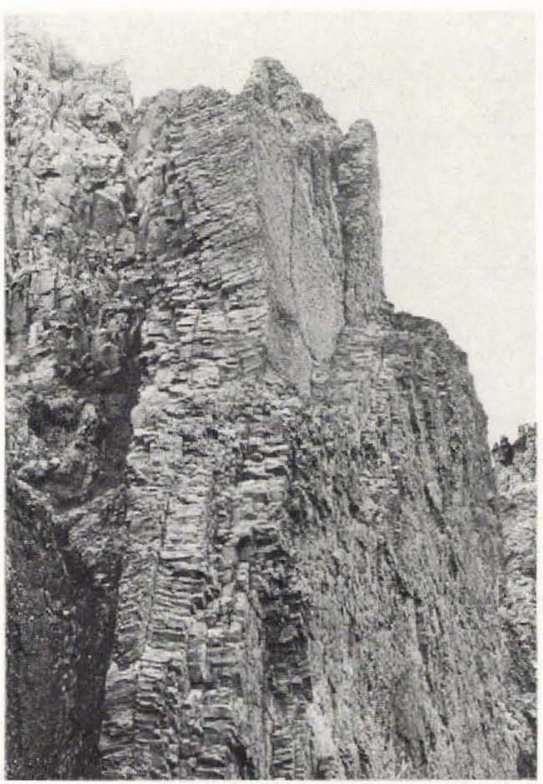

Fig. 25.6 to $8 \mathrm{~m}$ thick columnar jointed basalt with native iron and sulphides, cutting through Rinks Dal member basalts. The Nãngissat-Kitdlît dyke at Luciefjeld, southern Disko.

lump obtained by K. J. V. Steenstrup last century from near the settlement Diskofjord led to the discovery of an $8 \mathrm{~m}$ thick sediment contaminated basaltic dyke, which can be followed for at least $17 \mathrm{~km}$ from $2.5 \mathrm{~km}$ east of Nãngissat towards the north. The dyke is nearly vertical and cuts through both the gneiss ridge and the covering Rinks Dal member basalts. It is regularly columnar jointed (fig. 25) and consists of an olivine microporphyritic native iron bearing basalt containing modified gneiss xenoliths and scattered modified sedimentary xenoliths varying in appearance from very fine-grained glassy black types to coarse-grained graphite-plagioclase-spinel-bodies. A centimetre thick chill zone with well preserved glass grades inwards into a fine to medium-grained well crystallized light grey basalt looking aphyric because the groundmass grain size is larger than the size of the olivine. In the dyke a sulphide-iron segregation body was discovered about $2 \mathrm{~km}$ east of point 943 in Eqalúnguarqat qáqait by $\mathrm{F}$. Ulff-Møller who is preparing a detailed description of it.

Fundal (1975) gave numerous new observations on intrusive rocks in southern Disko. A new native iron bearing dyke, followed for about $10 \mathrm{~km}$ along a trend $\mathrm{N}-\mathrm{S}$ from Kitdlit (Fortunebay) through Luciefjeld was discovered and described by him in detail. The dyke cuts through the Disko gneiss ridge at Kitdlît.

Field investigations of this dyke showed it to be very similar to the iron-bearing dyke east of Nãngissat in Disko Fjord, and this is confirmed by petrography and chemistry (Table 9 , no. 4 and 5). Since the two dykes are dissimilar to any other dyke intrusives known from southern Disko, and since they are nearly on strike, it is concluded that they are part of the same intrusion. This intrusion, being more than $35 \mathrm{~km}$ long, is by far the most extensive native iron bearing dyke yet observed.

The rocks are slightly quartz normative basalts with a very high normative orthopyroxene component. In composition they are dissimilar to the Rinks Dal member lavas they cut through but strongly resemble some olivine microporphyritic pahoehoe lavas mentioned 
from the Niaqussat member north of Rinks Dal in north-western Disko (Pedersen, 1975). An analysis is given for comparison in Table 9, no. 6. It is very likely that the dykes were emplaced during the Niaqussat member volcanism. They may have been feeders to such lavas, now removed by erosion.

Fundal (1975, p. 15) described a body, called the 'Y-dyke', which trending perpendicular to the iron-bearing dyke at Kitdlît was considered part of this dyke. The 'Y-dyke' displays ultramafic chemistry and mineralogy of a type quite unique for the Tertiary volcanic rocks of West Greenland, and this was used by Fundal (1975) as an argument for the derivation of the native iron of Disko from deep-seated sources in the mantle or in the crust. A field inspection of the 'Y-dyke' showed it, however, to be an ultramafic sheet-like body, concordant with the enclosing gneisses, well foliated and strongly affected by amphibolite facies metamorphism. The 'Y-dyke' is definitely of Precambrian age and unrelated to the native iron of Disko.

The iron-bearing dyke cuts through gneisses and this was used by Fundal (1975) as an argument for a non-sedimentary origin of characteristic pyrometamorphic xenoliths and xenocrysts both in this dyke, and in all iron-bearing volcanic rocks elsewhere.

Alternatively, I interpret the dyke as evidence of very extensive horizontal movements of melts flowing in dyke channels during the emplacement of the Tertiary volcanic rocks. Such channel bodies are known from the Hammers Dal Complex (Ulff-Møller, this report) and possibly from the Hanekammen Complex (Pedersen, 1975) in north-western Disko.

Finally, a slightly sediment contaminated but native iron free dyke has been seen cutting the gneiss about $5 \mathrm{~km}$ west of the Nãngissat dyke near the settlement of Diskofjord. It strikes $\mathrm{N}-\mathrm{S}$.

\section{A cross-bedded breccia dyke}

A dyke intrusion of a type most unusual for the area was found cutting the Rinks Dal member lavas at Nûk kangigdleq at Uivfaq. The intrusion looks from the distance as a grey dyke, striking NE, composed of several, irregular, connected, vertical parts, being up to 15 $\mathrm{m}$ thick. It can be followed for several kilometres towards the north-east. Only the southernmost outcrop has been briefly visited and shows the body to be an intrusive breccia, veined by thin dykes of nearly aphyric basalt. The breccia shows dipping from $0^{\circ}$ to $30^{\circ}$ towards the north. It is composed of fragments varying in size from one metre down to less than one millimetre. Some fragments are sharp-edged while others are rounded. Some bodies look bomb or pillow like and are regularly jointed into small segments. The fragments are various basaltic rocks, characteristic being pyroxene and feldsparphyric types. The dyke must have originated through a local high level gas enrichment of a basaltic magma, which from that stage pierced upwards as a largely mechanical mixture of solid fragments. Vivid turbulent movements of solids produced the sedimentary well-sorted structures now observed.

\section{Fracture and dyke intrusion patterns}

The plateau basalts of south Disko still form a nearly horizontal lava plateau, which has only been affected by regional movements or tiltings to a minor degree. A considerable number of joints and faults cut through the plateau but the actual displacements have been 
small. Most common are faults and joints with a N-S trend. Zones specially affected by fracturing can be recognized. Most prominent is a wide zone of N-S extension running from east of Uivfaq through Nordfjordspasset, Stordal, Steenstrup Dal and up to the valley of Kûgánguaq in northern Disko. This zone is close to the western margin of the Disko gneiss ridge, which seems to have acted as a structural hinge before; during and after the volcanic episode. Towards the west, the plateaus have suffered regional downwarping (Pedersen, this report).

Nearly all dykes strike NW to NNE and the coast exposures have been scanned for dykes in order to reach estimates of the possible dilation of the area. In the eastern part of the area from Godhavn to Qeqertârssuk on the north coast of Disko Fjord the dykes amount to a mere 0.25 to 0.30 per cent. In the area towards the west, the dykes increase in number to amount to $\mathbf{0 . 5}$ to $\mathbf{0 . 6}$ per cent. Even if a few dykes have been missed due to the Quaternary cover in valleys, and if a pure dilational intrusion mechanism is assumed, it can safely be concluded that the dilation of the area was negligible during the volcanism. The thickness of the dykes vary from a few metres to $15 \mathrm{~m}, 4$ to $6 \mathrm{~m}$ being especially common.

Hald (1973) reports that the dykes of western Nûgssuaq rarely attain a thickness above 5 $\mathrm{m}$. Elder (1975) has reported gravimetric evidence for strong crustal thinning in that area; it is interesting that the southern Disko dykes often attain a thickness exceeding what is found in western Nûgssuaq. A similar relation was found for the thickness of the feldsparphyric basaltic lavas (Pedersen, this report).

Presumably this is caused by differing eruptive conditions in areas with thick and thin crust. If upwelling from deep mantle sources is similar in the two areas, larger pools will tend to accumulate under thick crust where eruptive conditions are more rarely attained (Elder, 1976).

\section{Dykes as evidence of a regional state of tension in the Disko - Disko Bugt area}

Although the dykes have not been investigated in detail over a large part of the DiskoDisko Bugt area, the evidence available permits some conclusions to be drawn about the regional tensional system during their emplacement. Henderson (1973) pointed out that two doleritic master dykes, intruded into the Precambrian basement over a distance of more than $400 \mathrm{~km}$ from the Umanak to the Jakobshavn area, indicated a fossil tensional field. These dykes were considered as infilled tension fractures parallel to a large graben system extending from Melville Bay towards the south-south-east to the bottom of Disko Bugt.

Fig. 26 shows, very schematically, prominent pre-Quaternary tensional fields as they are indicated by dyke systems. Two systems dominate, namely one which strikes NNW to WNW and another striking $\mathrm{N}$ to NNE.

The first system, with a dominant dyke trend around NW, is found at least from the southern Itivdle valley on Nûgssuaq and southwards through northern Disko and southeastern Disko (1:100 000 map sheets Agatdal and Qutdligssat). It was possibly this system that was recorded on its magnetic field out into Disko Bugt by Denham (1974).

In north-western Disko, the system is also present, and southwards the proportion of the dykes with this trend decreases so that in south-western Disko they are very subordinate. The dyke types found show that the supposed tension system was active during and after the eruption of the exposed lavas on Disko. 


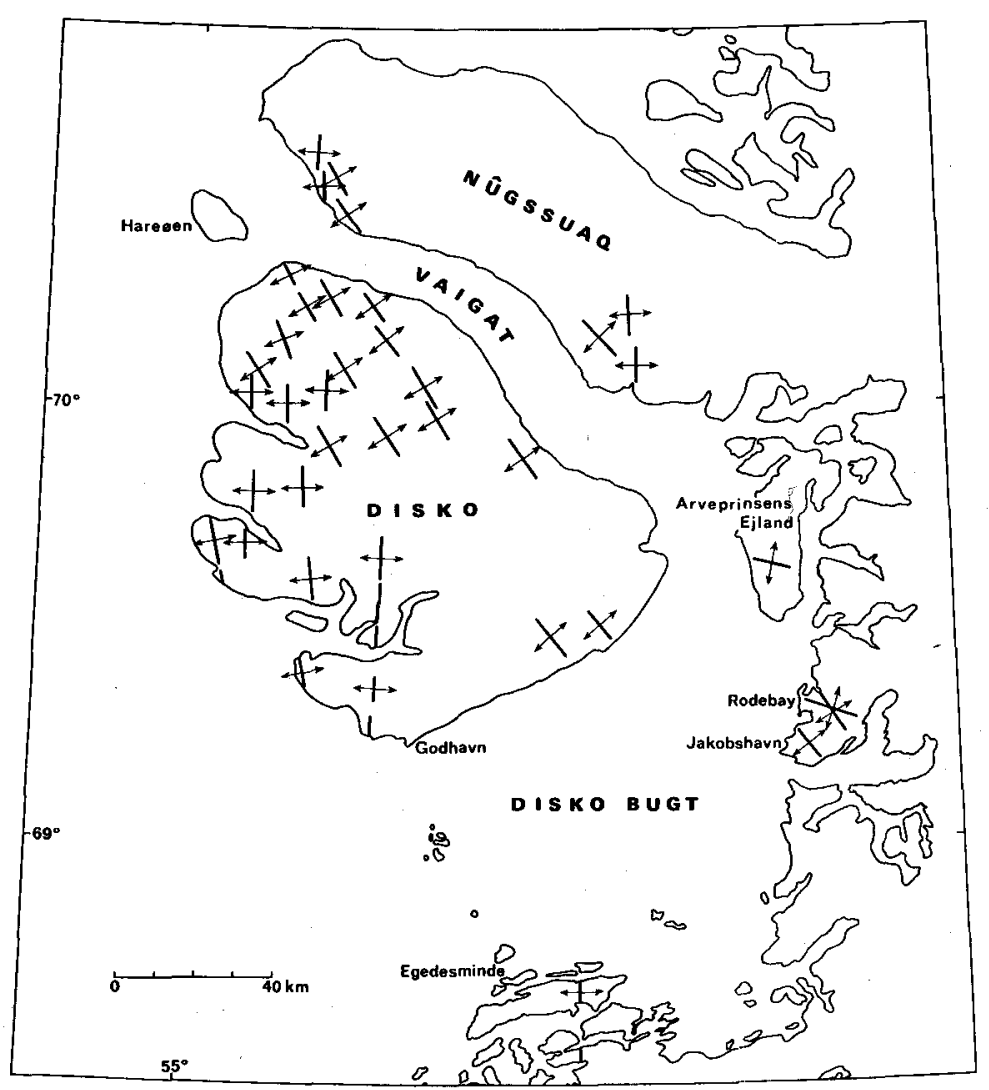

Fig. 26. Prominent tension fields as shown from the dyke distribution pattern in the Disko - Disko Bugt area.

The persistence of the dyke system is also traceable further afield: in north-east Disko Bugt Escher \& Burri (1967) found about 20 dolerite dykes cutting the Precambrian. They strike NNW to WNW and presumably belong to the system. The dykes were considered related to the Tertiary lavas although some of the dykes may well be older than the Tertiary. Thus a prominent dyke just south of Rodebay north of Jakobshavn shows a strongly western trend pointing towards the pre-Tertiary dykes from Disko Fjord.

Thus, there is evidence of a persistent NE-SW tension field before, during and after the volcanism on Disko. This tension field coincides with the tension expected with the supposed continental splitting around 60 to $47 \mathrm{~m} . \mathrm{y}$, ago irrespective of whether there was widespread foundering of continental crust (van der Linden, 1975) or continental spreading (Keen et al., 1972, 1974).

The second dyke system was related to an east-west tension field, with a dominant dyke trend of N to NNE. Since picritic dykes with such a trend are only rarely found, it seems to have been active mostly during the Maligât Formation volcanism and later. The proportion of dykes with such a trend gradually increases when moving westwards in northern Disko, 
and the trend dominates along the west, south-west and south coasts of Disko. The ironbearing dyke at Kitdlît - Nängissat as well as most ferrotholeiitic dykes of southern Disko belong to this system. Dykes with such a trend are found parallel to the Disko gneiss ridge and its supposed extension up through Disko from south to north. The system seems related to the block faulting and horst movements in the region. Its southernmost extension is a tholeiitic dyke, the 'Globule dyke', extending for more than $60 \mathrm{~km}$, trending $\mathrm{N}-\mathrm{S}$, east of Egedesminde (Ellitsgaard-Rasmussen, 1952). Henderson (1973) related this dyke to a $\mathrm{N}-\mathrm{S}$ trending graben system in the Baffin Bay.

\section{Summary}

The dyke intrusions in southern Disko include the following generations:

(1) Pre-Tertiary tholeiitic basalt poor in $\mathrm{TiO}_{2}$ and $\mathrm{P}_{2} \mathrm{O}_{5}$. These may be related to dolerites intruding the Precambrian rocks north-east of Disko Bugt.

(2) Feldsparphyric tholeiitic basalts, possibly related to feldsparphyric lavas from the Rinks Dal and Niaqussat members.

(3) Contaminated olivine microporphyritic basalts with sulphides and iron, resembling some Niaqussat member lavas. The dykes seem to indicate that the Niaqussat member lavas were erupted over much larger areas than where they are now found.

(4) Late ferrotholeiitic basalts rich in titanium. Some of these were possibly feeders to lavas, no longer preserved.

The absence of alkalic dykes suggest that late alkaline volcanism in south and south-west Disko never occurred.

The very low dyke intensity found indicates a negligible dilation of the area.

The dyke intrusion pattern suggests that the Disko - Disko Bugt area was in a state of tension for millions of years and that the tension was related to a stage of early continental splitting or foundering.

Another dyke system presumably emplaced in an east-west tensional state was probably related to horst movements, continental marginal collapse and graben formation in a $\mathrm{N}-\mathrm{S}$ extending system in the Baffin Bay as suggested by Henderson (1973).

\section{References}

Bøggild, O. B. 1953: The mineralogy of Greenland. Meddr Grønland 149, 4, 442 pp.

Clarke, D. B. 1975: Tertiary basalts dredged from Baffin Bay. Can. J. Earth Sci. 12, 1396-1405.

Denham, L. R. 1973: Marine geophysical survey between $68^{\circ} 30^{\prime} \mathrm{N}$ and $73^{\circ} 30^{\prime} \mathrm{N}$, West Greenland. Rapp. Grønlands geol. Unders. 55, 14-18.

Denham, L. R. 1974: Offshore geology of northern West Greenland. Rapp. Grønlands geol. Unders. 63, 24 pp.

Deutch, E. R. \& Kristjansson, L. D. 1974: Paleomagnetism of Late Cretaceous - Tertiary volcanics from Disko Islands, West Greenland. Geophys. J. R. Astron. Soc. 39, 343-360.

Drever, H. I. \& Livingstone, D. F. 1948: Some basaltic rocks from West Greenland. Proc. roy. Soc. Edinb. B, 63, 97-114.

Elder, J. W. 1975: A seismic and gravity study of the western part of the Cretaceous-Tertiary sedimentary basin of central West Greenland. Rapp. Grønlands geol. Unders. 69, 5-9.

Elder, J. 1976: The bowels of the earth. Oxford University Press, $222 \mathrm{pp}$. 
Ellitsgaard-Rasmussen, K. 1952: A west Greenland globule dike. Meddr dansk geol. Foren. 12, 83-101. Escher, A. \& Burri, M. 1967: Stratigraphy and structural development of the Precambrian rocks in the area north-east of Disko Bugt, West Greenland. Rapp. Grønlands geol. Unders. 13, 28 pp.

Fundal, E. 1975: The Uivfaq dike and related hybrid dykes from southern Disko, West Greenland. Meddr Grønland 195, 28 pp.

Giesecke, C. L. 1823: On the mineralogy of Disko Island. Trans. roy. Soc. Edinb. 9, 263-272.

Hald, N. 1973: Preliminary results of the mapping of the Tertiary basalts in western Nûgssuaq. Rapp. Grønlands geol. Unders. 53, 11-20.

Hald, N. 1976: Early Tertiary flood basalts from Hareøen and western Nûgssuaq, West Greenland. Bull. Grønlands geol. Unders. 120, $36 \mathrm{pp.}$

Henderson, G. 1973: The geological setting of the West Greenland basin in the Baffin Bay region. Pap. geol. Surv. Can. 71-23, 521-544.

Irvine, T. N. \& Baragar, W. R. A. 1971: A guide to the chemical classification of the common volcanic rocks. Can. J. Earth Sci. 8, 523-548.

Keen, C. E., Barrett, D., Manchester, K. S. \& Ross, D. I. 1972: Geophysical studies in Baffin Bay and some tectonic implications. Can. J. Earth Sci. 9, 239-256.

Keen, C. E., Keen, M. I., Ross, D. J. \& Lack, M. 1974: Baffin Bay: small ocean basin formed by sea-floor spreading. Bull. Am. Ass. Pet. Geol. 58, 1089-1108.

Krueger, H. K. E. 1928a: Über eine sogenannte Basaltbreccie in der Kreide-Tertiær-Formation von Westgrönland. Notizbl. Ver. Erdk. Darmstadt 5, 270-281.

Krueger, H. K. E. 1928b: Zur Geologie von Westgrönland, besonders der Umgebung der Disko-Bucht und des Umanak-Fjordes. Meddr Grønland 74, 97-136.

Munck, S. \& Noe-Nygaard, A. 1957: Age determination of the various stages of the Tertiary volcanism in the West Greenland basalt province. Rep. 20th. int. geol. Congr. Mexico (1), 1, 247-256.

Park, I., Clarke, D. B., Johnson, J. \& Keen, M. J. 1971: Seaward extension of the West Greenland Tertiary volcanic province. Earth planet. Sci. Lett. 10, 235-238.

Pauly, H. 1969: White cast iron with cohenite, schreibersite and sulphides from Tertiary basalts on Disko, Greenland. Meddr dansk geol. Foren. 19, 8-26.

Pedersen, A. K. 1975: New mapping in north-western Disko. Rapp. Grønlands geol. Unders. 69, 25-32.

Rink, H. 1853: Udsigt over Nordgrönlands Geognosi, især med Hensyn til Bjergmassernes mineralogiske sammensætning. $K$. danske Vidensk. Selsk. Skr. (5), 3, 71-98.

Steenstrup, K. J. V. 1882: Om Forekomsten af Nikkeljern med Widmannstättenske Figurer i Basalten i Nord-Grønland. Meddr Grønland 4, 113-132.

Steenstrup, K. J. V. 1883: Kjendskab til de geognostiske og geographiske forhold $\mathrm{i}$ en Del af Nord-Grønland. Meddr Grønland 4, 175-242.

Steenstrup, K. J. V. 1900: Beretning om en Undersøgelsesrejse til Øen Disko i Sommeren 1898. Meddr Grønland 24, 249-306.

Vaasjoki, O. 1965: On basalt with native iron in Disko, West Greenland. C.r. Soc. geol. Finlands 37, 85-98.

van der Linden, W. J. M. 1975: Crustal attenuation and sea-floor spreading in the Labrador Sea. Earth Planet. Sci. Lett. 27, 409-423. 